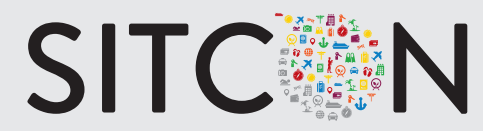

\title{
UPRAVLJANJE KULTURNIM RESURSIMA U FUNKCIJI UNAPREĐENJA PONUDE KULTURNOG TURIZMA VRNJAČKE BANJE
}

\author{
Milena Podovac ${ }^{1 \star}$, Melita Jovanović Tončev ${ }^{2}$ \\ ${ }^{1}$ Univerzitet u Kragujevcu, Fakultet za hotelijerstvo i turizam u Vrnjačkoj Banji, Republika Srbija \\ ${ }^{2}$ Univerzitet Singidunum, Beograd, Republika Srbija
}

\begin{abstract}
Apstrakt:
Predmet analize u ovom radu su kulturni resursi Vrnjačke Banje i mogućnosti da se adekvatnijim upravljanjem unapredi postojeća ponuda kulturnog turizma. Vrnjačka Banja poseduje kulturno-istorijsko nasleđe, koje čini veliki broj spomen obeležja, manifestacije, crkve i manastiri, bogata tradicija, folklor, gastronomija i dr. Unapređenje ponude kulturnog turizma i veća uključenost destinacijskog menadžmenta doprineli bi afirmaciji Vrnjačke Banje kao destinacije, koja neguje svoju kulturu i tradiciju i nastoji da istu približi turistima. Cilj ovog rada jeste da se na bazi analize kulturnih resursa, definišu smernice za unapređenje ponude kulturnog turizma Vrnjačke Banje.
\end{abstract}

\author{
Ključne reči: \\ kulturni turizam, \\ kulturni resursi, \\ Vrnjačka Banja, \\ upravljanje, \\ destinacija.
}

\section{UVOD}

Kulturni turizam povezuje dva pojma, kulturu i turizam. Kultura je značajn element turističkog proizvoda, koji doprinosi različitosti destinacije na globalnom tržištu. Istovremeno, turizam predstavlja važan instrument za razvoj kulture i stvaranje prihoda kako bi se podržala i ojačala kulturna baština, kultura i kreativnost. Uspostavljanje jake veze između kulture i turizma omogućava destinaciji da bude atraktivna i konkurentna kako bi se ostvario veći turistički promet, investiciona ulaganja i otvaranje novih radnih mesta (Kotollaku \& Margariti, 2015).

Kulturni turizam predstavlja predmet istraživanja velikog broja naučnih radova (Silberberg, 1994; Seale, Hughes, \& Richards, 1996). Prema konceptualnoj definiciji, kulturni turizam predstavlja kretanje ljudi ka kulturnim atrakcijama van mesta njihovog prebivališta, sa namerom da prikupe nove informacije i iskustva kako bi zadovoljili svoje kulturne potrebe. Prema tehničkoj definiciji, kulturni turizam podrazumeva sva kretanja ljudi ka posebnim kulturnim atrakcijama, kao što su muzeji, mesta sa kulturnim nasleđem, umetniče i kulturne manifestacije van mesta stalnog prebivališta itd. (Benson, 2014). Jednu od najprihvaćenijih definicija kulturnog turizma dao je Greg Richards (1996), a prema kojoj kulturni turizam označava kretanje ljudi, koje je uzrokovano kulturnim atrakcijama izvan njihovog uobičajenog mesta stanovanja, sa namerom sakupljanja novih informacija i iskustava kako bi zadovoljili svoje kulturne potrebe.

Da bi razvoj kulturnog turizma bio održiv, neophodan je adekvatan sistem upravljanja kulturnom baštinom. Kada se o održivosti ne bi vodilo računa, resursi bi bili nepovratno izgubljeni ili trajno oštećeni. Da do toga ne bi došlo, menadžment kulturnog turizma na svim nivoima upravljanja (lokalni, regionalni, republički), u proces definisanja strate- gija održivog razvoja, pored predstavnika lokalne zajednice, mora uključiti i stručnjake za zaštitu i lica, koja upravljaju spomenicima i kulturnim znamenitostima, turističke radnike, učesnike iz privrede i dr. (Đukić-Dojčinović, 2005).

Prema podacima Svetske turističke organizacije (Urošević, 2010), kulturni turizam obuhvata $40 \%$ od ukupnog broja putovanja u međunarodnom turizmu. Na godišnjem nivou, stopa rasta kulturnog turizma iznosi 15\%. Stručnjaci procenjuju da je više od 50\% turističkih poseta Evropi motivisano upravo obilascima lokaliteta kulturnog nasleđa i da su to turisti sa visokim stepenom obrazovanja.

Vrnjačka Banja predstavlja jedno od najpoznatijih i najposećenijih banjskih lečilišta u Republici Srbiji. Na turističkom tržištu je pozicionirana kao destinacija savremenog zdravstvenog i banjskog turizma. Postojeća turistička tražnja Vrnjačke Banje može se podeliti na turiste, koji dolaze zbog lečenja i turiste, koji posećuju Banju zbog razvijene ponude zdravstvenog, spa\&wellness i sportsko-rekreativnog turizma. S obzirom da je kulturni turizam zasnovan na promovisanju kulturnih vrednosti destinacije ili regije, postavlja se pitanje da li takav oblik turizma može unaprediti postojeću ponudu Vrnjačke Banje i obezbediti aktivnosti za turiste.

\section{ANALIZA KULTURNIH RESURSA VRNJAČKE BANJE}

Vrnjačka Banja poseduje reprezentativno kulturno nasleđe, koje može biti iskorišćeno za kreiranje jedinstvenog turističkog proizvoda. Ovu destinaciju karakteriše snažan kulturni identitet, koji se ogleda u lokalitetima kulturnoistorijskog nasleđa, a koji svedoče o istorijskom nastanku i razvoju ovog banjskog lečilišta. Arheološki nalazi na lokalitetima svedoče o naseljenosti još u praistoriji. $U$ ataru sela Vrnjci, na mestu Lađarište, nalazi se višeslojno arheološko 
nalazište, većeg značaja (otkriveni su ostaci kuća, fragmenti posuđa, radionica za izradu kamenog oruđa, medijalna keramika). Najznačajniji nalazi su ostaci iz rimskog perioda (Opština Vrnjačka Banja, 2013). Za Vrnjačku Banju najznačajniji sakralni objekat je Hram rođenja Presvete Bogorodice, koji se nalazi na Čajkinom brdu. Hram je podignut 1834. godine za vreme vladavine kneza Miloša Obrenovića. Ktitor manastira je Hadži Jefimije Popović, protojerej iz Vrnjačke Banje. Hram je posvećen rođenju Presvete Bogorodice (Vrnjačka Banja, 2015).

Graditeljski razvoj Vrnjačke Banje vezuje se za poslednju deceniju XIX i prve decenije XX veka, kao period kada se formira karakteristično jezgro različitih graditeljskih stilova (Borović-Dimić \& Dimić, 2003). Iako je vremenom banjska opština modernizovana izgradnjom velikog broja stambenih objekata, zadržala je atraktivnost, koju joj daju tradicionalne građevine. Graditeljstvo na području Vrnjačke Banje prepoznatljivo je po starim vilama. Reprezentativan primer graditeljskog nasleđa je Zamak Belimarković, koji je sagrađen je između 1882. i 1887. godine za generala Jovana Belimarkovića. Ovaj letnjikovac podignut je iznad granice ondašnjeg banjskog reona, na padini iznad izvora Topla voda. Zdanje je izgrađeno u duhu romantičarskog istorizma, sa renesansnim elementima po uzoru na poljske vile severne Italije. Dvorac je proglašen kulturnim dobrom od velikog značaja (Turistička organizacija Srbije, 2015).

Spomen obeležja su karakteristična za jezrgo banjske opštine (spomenici, spomen česme, spomen ploče, spomen biste i dr.). Za razvoj kulturnog turizma, značajan je Park skulptura, koji se nalazi u banjskom parku. U okviru manifestacije Vrnjačka jesen, održan je simpozijum Skulptura u slobodnom prostoru 1965. godine. Od te godine, vrnjački park oplemenjuju savremena vajarska ostvarenja jugoslovenskih i stranih autora. U Parku skulptura, trajno su postavljenja ostvarenja učesnika Vajarskog simpozijuma (Ruđinčanin \& Topalović, 2008). Umetnička vrednost ovih skulptura je velika i doprinosi atraktivnosti banjskog parka za turiste.

Vrnjačka Banja je destinacija, koju karakteriše bogato folkorno nasleđe. Zahvaljujući kulturno-umetničkim društvima KUD Abrašević i KUD Izvor, folklorna tradicija nije zaboravljena. Jedan od načina, na koji se neguje folklor i tradicionalna muzika su manifestacije Kad lipe cvetaju i Razigrano proleće. Negovanje tradicionalnih vrednosti manifestuje se kroz stare zanate i njihovo oživljavanje u cilju razvoja turizma. Manifestacija Zlatne niti ima za cilj očuvanje tradicije i narodnog stvaralaštva. Predstavlja tradicionalnu žensku etno-turističku manifestaciju koja okuplja oko 500 do 1000 učesnika, uglavnom žena iz cele bivše Jugoslavije (Upoznaj Srbiju, 2015). Karakteristično je to da žene prikazuju svoje umeće u pripremi tradicionalnih jela, veženju i pletenju i dr.

Najznačajnija insttitucija, koja neguje kulturu, istoriju i tradiciju Vrnjačke Banje je Kulturni centar. Institucija je javna ustanova u oblasti kulture i poseduje bioskopsko-pozorišnu dvoranu, Zamak kulture sa galerijskim i muzejskim prostorom i Amfiteatar kapaciteta 1500 sedišta. Kulturni centar je organizator jedne od najznačajnijih kulturnih manifestacija u Srbiji pod nazivom Vrnjačke kulturne svečanosti. Stalnu postavku čine tri izložbe: Ladarište - praistorija Vrnjaca, Etnografsko nasleđe Vrnjačke Banje i Spomen soba generala Belimarkovića, dok se u van sezoni postavlja Umetnička zbirka Zamka kulture (Vrnjačka Banja, 2015). Značaj ove institucije za razvoj kulturnog turizma ogleda se u očuvanju, zaštiti i prezentaciji materijalnog kulturnog nasleđa, organizaciji kulturnih manifestacija, očuvanju i unapređivanju lokalne kulture i dr.

Vrnjačka Banja je oduvek bila poznata po manifestacijama. Prvobitne manifestacije bile su skromnih razmera i posećenosti. Sa intenzivnijim razvojem turizma, manifestacije su postale masovna pojava i samim tim jedan glavnih motiva dolaska turista. Naznačajnije kulturne manifestaicje su sledeće:

- Festival filmskog scenarija. Ideja o organizaciji ovog festivala nastala je 1974. godine u cilju afirmacije domaćeg filma. Inicijatori Festivala bili su Kulturni centar Vrnjačke Banje, Udruženje filmskih autora i Udruženje filmskih glumaca. Za 26 godina u takmičarskoj konkurenciji prikazano je 275 filmova. Održano je 26 simpozijuma posvećenih scenarističkim problemima. Broj učesnika simpozijuma je oko 600 učesnika (Festival filmskog scenarija, 2015). Manifestacija se tradicionalno održava na letnjoj pozornici na Čajkinom brdu.

- Međunarodni festival klasične muzike. Pored mnogobrojnih koncerata, u okviru festivala održava se i pedagoški program sa kursevima violine i kamerne muzike (Vrnjačka Banja, 2015).

- Književno leto. Program ove manifestacije je fokusiran na promociju književnog stvaralaštva. Predstavlja program iz oblasti književnog stvaralaštva, koju čine književni portreti istaknutih pisaca, promocije knjiga, književnih regija i gradova Srbije, književnih manifestacija i dobitnika književnih nagrada, kao i tribine na aktuelne teme iz istorije, filozofije, društvenih nauka, politike, teologije i dr. (Vrnjačka Banja, 2015). U okviru programa Književnog leta održano je nekoliko stotina književnih manifestacija, čiji su učesnici bili: Desanka Maksimović, Dobrica Ćosić, Borislav Pekić, Vida Ognjenović, Grozdana Olujić, Slobodan Selenić, Mira Alečković i dr. (Ruđinčanin \& Topalović, 2008).

- Dani Danila Bate Stojkovića. Obeležavaju se u prvoj polovini avgusta u čast jedne od glumca Danila Bate Stojkovića. Organizator ove manifestacije je Udruženje Prijatelji Bate Stojkovića. Manifestacija se održava na otvorenom u restoranu Stara Srbija, koju je poznati glumac najčešće posećivao (Filmske radosti, 2015). Prateći sadržaj ove manifestacije čini okupljanje glumaca, odnosno prijatelja Danile Bate Stojkovića i projekcija filmova, u kojima je on igrao.

- Na Desankin dan. Turistička organizacija Vrnjačke Banje je u program manifestacija od 2013. godine uvrstila manifestaciju Na Desankin dan, u čast pesnikinje Desanke Maksimović. Manifestacija se održava 16-og maja na rođendan ove istaknute i za Vrnjačku Banju vrlo značajne pesnikinje. Program manifestacije uključuje pozorišni, recitatorski i muzički sadržaj.

U okruženju Vrnjačke Banje, nalaze se značajni srpski srednjovekovni manastiri i gradovi, a koji su veoma atraktivni i kao ponuda u segmentu kulturnog turizma. Jedan broj tih turističkih atrakcija nalazi se u basenu Ibra - Ibarska kraljevska dolina sa manastirima iz XII i XIII veka: Žiča, Studenica, Gradac, Petrova crkva, Sopoćani i Đurđevi Stupovi i takvim srednjovekovnim gradovima kao što su Ras i Maglič, do kojih se od Vrnjačke Banje stiže preko Kraljeva i Novog Pazara. Podjednako je atraktivno i arhitektonsko 
nasleđe moravske škole (kraj XIV - XV vek) u blizini Vrnjačke Banje kao što su manastiri Naupara, Lazarica, Veluće, Rudenica, Kalenić, Ljubostinja i srednjovekovni grad Koznik (Republički zavod za zaštitu spomenika kulture, 2007). Na osnovu predočenih podataka, možemo zaključiti da postojeći kulturni resursi poseduju potrebne kvalitete za kreiranje značajne ponude kulturnog turizma, koja je prvenstveno usmerena prema unapređenju celokupne ponude Vrnjačke Banje kao turističke destinacije.

\section{SMERNICE ZA UNAPREĐENJE PONUDE KULTURNOG TURIZMA}

Kako bi ponuda kulturnog turizma Vrnjačke Banje bila unapređena, predlažemo sledeće smernice:

1. Upotpunjavanje ponude kulturnog turizma dodatnim sadržajima.

- Uključiti u paket aranžmane aktivnosti kao što su izleti, obilasci lokaliteta kulturno-istorijskog nasleđa, prisustvo kulturnim manifestacijama, upoznavanje sa arhitekturom jezgra Banje, upoznavanje sa tradicijom lokalne zajednice i sl.

- Organizovati obilaske samog jezgra Vrnjačke Banje uz pratnju vodiča, koji bi goste upoznali sa istorijskim razvojem, znamenitim lokalitetima i ličnostima.

- Posebno usmeriti turističke posete prema starim vilama, koje su zadržale autentičan arhitektonski stil nekadašnje Banje, jer one nisu još uvek dovoljno prepoznate kao potencijal za uključivanje u ponudu kulturnog turizma.

- U tom pravcu, na osnovu nekadašnjih banjskih razglednica, lokalna turistička organizacija može utvrditi koje su to znamenite i očuvane građevine kako bi organizovala za turiste obilaske istih. Nosioci takvog projekta bili bi lokalna turistička organizacija, Kulturni centar i vlasnici vila.

- Kako bi turisti bili upoznati sa lokalitetima kulturnog-istorisjkog nasleđa, isti moraju biti obeleženi turističkom signalizacijom srpskom i engleskom jeziku.

- U cilju održivog razvoja kulturnog turizma, potrebno je lokalitete održavati, naročito kada se radi o skulpturama i spomen obeležjima u parku.

- Povećati broj književnih večeri, koncerata klasične muzike i izložbi.

- Kombinovati aktivnosti aktivnog odmora i obilaska lokaliteta kulturno-istorijsko nasleđa kako bi se stvorila osnova za kreiranje potpuno nove ponude. Primera radi, to mogu biti aktivnosti kao što su šetnje obroncima planine Goč, branje lekovitog bilja i cveća, ekstremni sportovi i druge aktivnosti u kombinaciji sa obilascima lokaliteta kulturnog-istorijskog nasleđa.

2. Očuvanje graditeljskog nasleđa u cilju implementacije u ponudu kulturnog turizma.

- Vrnjačka Banja poseduje veliki broj objekata, koji svedoče o nekadašnjem stilu gradnje objekata, a koji mogu biti deo ponude kulturnog turizma. Kako bi se očuvala tradicionalna arhitektura, neophodne su mere kontrole gradnje u neposrednom okruženju značajnih objekata. Osnivanje posebnog fonda za finansiranje zaštite lokaliteta kulturno-istorijskog nasleđa doprinelo bi ne samo očuvanju, već kreiranju dodatnih sadržaja za turiste.

- Intenzivna saradnja subjekata turističke privrede i institucija kulture.

- Unapređenje ponude kulturnog turizma Vrnjačke Banje zahteva saradnju institucija kulture i nosilaca turističke ponude (hoteli, ugostiteljski objekti, turističke agencije, lokalna turistička organizacija i dr.). Dosadašnji razvoj kulturnog turizma zasnivao se na pojedinačnim naporima da se kreira jedinstven proizvod i privuče turistička tražnja. U budućnosti, usaglašavanje interesa pomenutih subjekata može doprineti razvoju održivog i profitabilnog proizvoda. Institucije kulture i Turistička organizacija moraju usmeriti svoje aktivnosti prema osmišljavanju novih sadržaja i promociji istih, ali isto tako moraju uključiti usluge pojedinačnih subjekata u ponudu. Inovacija proizvoda kulturnog turizma Vrnjačke Banje može biti nova manifestacija, kulturna ruta, upoznavanje sa tradicijom okolnih sela, manastirske ture, obilasci lokaliteta uz svetlosne i zvučne efekte i dr. Razvoj novih sadržaja zahteva angažovanje svih nosilaca razvoja turizma, institucija kulture i Turističke organizacije kroz radne grupe sa ciljem kreiranja i promocije aktivnosti za turiste, a koje mogu da doprinesu i promociji kulture i ostvarenju profita.

- Povezivanje ponude kulturnog turizma Banje sa ponudom okolnih gradova, koji imaju bogato kulturno-istorijsko nasleđe.

- U radu smo analizirali i kulturne resurse Raškog i Rasinskog okruga kako bi ukazali na postojanje mogućnosti za objedinjavanje ponude kulturnog turizma gradova, koji pripadaju pomenutim okruzima. Nosioci turističke ponude imaju mogućnost da organizuju izlete do Žiče, Magliča, Koznika, Kalenića i drugih lokaliteta, koji se nalaze u bližoj okolini Vrnjačke Banje. Na tom putu, turisti mogu biti gosti etno restorana, vinarija, seoskih domaćinstava kako bi se upoznali sa starim zanatima ili degustirali lokalne specijalitete. Primarnu ulogu u povezivanju ponude kulturnog turizma imale bi turističke organizacije pojedinih gradova, koje bi uz angažovanje privatnog $\mathrm{i}$ javnog sektora, omogućile turistima da tokom boravka u Banji uživaju u prirodnom ambijentu, tradiciji i kulturnoj baštini.

3. Kreiranje promotivnog materijala sa naglaskom na kulturnim resursima.

- Za privlačenje turističke tražnje, potrebno je na adekvatan način promovisati ponudu kulturnog turizma Vrnjačke Banje. Ključnu ulogu u kreiranju promotivnog miksa ima Turistička organizacija Vrnjačke Banje, zatim turističke agencije, hoteli, ugostiteljski objekti i dr. U kreiranje promotivnog miksa Vrnjačke Banje kao destinacije kulturnog turizma neophodno je uključiti Kulturni centar i druge institucije kulture. Promotivne aktivnosti bi uključivale sledeće:

- Kreiranje turističkog vodiča sa naglaskom na kulturnom nasleđu. 
- Kreiranje turističkog vodiča sa naglaskom na kulturnim manifestacijama.

- Kreiranje veb stranice u cilju vizuelne promocije kulturno-istorijskog nasleđa.

- Kreiranje promotivne kampanje u cilju promocije tradicionalnih vrednosti, odnosno starih zanata, folklora i gastronomije.

- Promocija kulturnih vrednosti Vrnjačke Banje na međunarodnim, regionalnim i nacionalnim sajmovima turizma; nacionalnim i lokalnim manifestacijama, muzičkim i filmskim festivalima, sajmovima hrane i pića (sajmovi vina, tradicionalne kuhinje i dr.).

- Izrada suvenira sa akcentom na lokalnim kulturnim motivima.

\section{REZIME}

Duga tradicija u razvoju organizovanog turizma, doprinela je da Vrnjačka Banja danas predstavlja jednu od najposećenijih destinacija Srbije. Sa druge strane, savremene tendencije na turističkom tržištu ukazuju na neophodnost kreiranja integrisanog turističkog proizvoda kako bi se zadovoljile potrebe tražnje. Kulturni turizam je jedan od oblika turističke aktivnosti, kojom je moguće unaprediti kvalitet postojeće ponude. Na osnovu analize postojećih kulturnih resursa, možemo zaključiti da Vrnjačka Banja poseduje bogato i raznovrsno kulturno nasleđe, veliki broj kulturnih manifestacija, a samim tim i neophodne preduslove za unapređenje postojeće ponude kulturnog turizma. Ključni faktor uspeha biće saradnja destinacijskog menadžmenta i institicija kulture. Dugoročno održiv razvoj kulturnog turizma, koji bi bio baziran na tradicionalnim kulturnim vrednostima i manifestacionom sadržaju, može znatno unaprediti postojeću ponudu Vrnjačke Banje kao turističke destinacije.

\section{LITERATURA}

Benson, E.I. (2014). Cultural Tourism and Sustainability in Nigeria. Mediterranean Journal of Social Sciences, 5(14), 649655. doi:10.5901/mjss.2014.v5n14p649.

Borović-Dimić, J., \& Dimić, B. (2003). Vrnjačka Banja na starim razglednicama. Vrnjačka Banja: Zavičajni muzej-Zamak kulture, Kulturni centar Vrnjačke Banje.

Đukić Dojčinović, V. (2005). Kulturni turizam. Beograd: Clio.

Festival filmskog scenarija. (2015). Preuzeto 19. maja 2015. sa http://www.screenfest.org.rs/index2013.htm
Filmske radosti. (2015). Prijatelji Bate Stojkovića. Preuzeto 19. maja 2015. sa http://www.filmske-radosti.com/ Tags/Prijatelji-Bate-Stojkovica

Hughes, H.L. (1996). Redefining Cultural Tourism. Annals of Tourism Research, 23(3), 707-709. doi: 10.1016/01607383(95)00099-2.

Kotollaku, M., \& Margariti, M. (2015). Cultural tourism in Gjirokastra. European Scientific Journal, 11(14), 294316.

Oština Vrnjačka Banja. (2013). Strategija održivog razvoja opštine Vrnjačka Banja 2013-2023. Vrnjačka Banja.

Republički zavod za zaštitu spomenika kulture. (2007). Spomeničko nasleđe Srbije. Beograd: Republički zavod za zaštitu spomenika kulture.

Richards, G. (1996). Cultural Tourism in Europe. CABI: Wallingford.

Ruđinčanin, O., \& Topalović, O. (2008). Vrnjačka Banja na početku XXI veka. Vrnjačka Banja: Narodna biblioteka Dr Dušan Radić, Kulturni centar Vrnjačke Banje.

Seale, R. (1996). A Perspective from Canada on Heritage and Tourism. Annals of Tourism Research, 23(2), 484-488. doi: 10.1016/0160-7383(96)90073-0.

Silberberg, T. (1994). Cultural Tourism and Business Opportunities for Museums and Heritage Sites. U: Quality Management in Urban Tourism: Balancing Business and Enviroment, Novembar 1994., pp. 1-11., Conference of School of Business, University of Victoria.

Turistička organizacija Srbije. (2015). Dvorac Belimarkovića, Vrnjačka Banja. Preuzeto 17. maja 2015. sa http://www. srbija.travel/kultura/dvorci/dvorac-belimarkovica-vrnjacka-banja/

Upoznaj Srbiju. (2015). Smotra narodnog stvaralaštva "Zlatne niti". Preuzeto 17. maja 2015. sa http://www.upoznajsrbiju.co.rs/manifestacija/smotra-narodnog-stvaralastva--zlatne-niti--439

Urošević, N. (2010). The Effects of Including the Cultural Sector in the Tourist Product of Destination - Strategic Considerations Regarding Istria as the Region of Cultural Tourism and Pula as the Euroepan Capital of Culture. U: Biennial International Congress. Tourism \& Hospitality Industry. 06.05.2010-08.05.2010. pp. 1305-1317. Opatija: Faculty of Tourism and Hospitality Management in Opatija.

Vrnjačka Banja. (2015). Crkve i manastiri Vrnjačke Banje. Preuzeto 17. maja 2015. sa http://www.vrnjacka-banja. com/vrnjacka-banja-crkve.php

Vrnjačka Banja. (2015). Kultura. Preuzeto 19. maja 2015. sa http://www.vrnjackabanja.co.rs/srpski/sadrzaj/kulturaglmeni

\title{
THE ROLE OF CULTURAL RESOURCES MANAGEMENT IN ENHANCING CULTURAL TOURISM OFFER OF VRNJAČKA BANJA
}

\begin{abstract}
:
This paper analyzes cultural resources of Vrnjačka Banja and possibilities for more adequate management of such resources with the aim of improving the existing cultural tourism offer. Vrnjačka Banja boats considerable cultural and historical heritage, including a vast number of memorials, events, churches and monasteries, rich tradition, folklore, gastronomy etc. The improvement of the cultural tourism offer and greater involvement of destination management would contribute to affirmation of Vrnjačka Banja as a destination nurturing its cultural and traditional heritage and striving to make it more accessible to tourists. The principal aim of this paper is to define guidelines for improving of cultural tourism offer of Vrnjačka Banja based on the analysis of the available cultural resources.
\end{abstract}

\section{Key words:}

cultural tourism, cultural resources, Vrnjačka Banja, management, destination. 